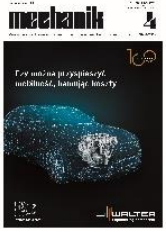

How to cite this article:

Authors: Sebastian Białasz, Łukasz Garbacz

Title of article: „ Characteristics of producing of the polymer films in blow film extrusion process”

Mechanik, No. 4 (2019)

DOI: https://doi.org/10.17814/mechanik.2019.4.31

\title{
Characteristics of producing of the polymer films in blow film extrusion process
}

\author{
SEBASTIAN BIAŁASZ \\ LUKASZ GARBACZ *
}

Mgr inż. Sebastian Białasz (s.białasz@pollub.edu.pl), https://orcid.org/0000-0002-2295-7757 - Politechnika Lubelska, Wydział Mechaniczny, Katedra Technologii i Przetwórstwa Tworzyw Polimerowych, Lublin,Polska

Mgr inż. Łukasz Garbacz (lukasz.garbacz@pollub.edu.pl) - Politechnika Lubelska, Wydział Mechaniczny, Katedra Technologii i Przetwórstwa Tworzyw Polimerowych, Lublin, Polska

In the article specification of blown film extrusion process of thermoplastics was presented. Methods of extrusion subject to products with determine characteristic received in the process where characteristic. In the research, extrusion blow molding process used polyethylene film PE-LD Malen-E were used. Extensive studies of the extrusion process and selected properties of polymer films were used.

KEYWORDS: thermoplastics polymers, blow film extrusion, process efficiency

\section{Characteristics of the blow film extrusion process}

The film is most often obtained in the processes of free blowing extrusion and extrusion through a slotted head. Basic condition for conducting the extrusion process is the appropriate temperature and pressure distribution of the material along the plasticizing system and extrusion head. Typical materials used in the film extrusion process are: polyethylene, polyvinyl chloride, polycarbonate, polyamide, polystyrene and cellulose acetate [1-3].

The blow film extrusion technological process consists in extruding a thin-walled pipe and immediately blowing it with low pressure air and drawing it out with a collecting device. When blowing, stretching occurs in the transverse direction, and when pulling - stretching in the longitudinal direction. To be able to better control the stretching processes, the extruded pipe is cooled directly behind the nozzle of the head in the air stream from the inflating device [3-5]. The film obtained in this way is considered to be non-oriented, and due to heat shrinkage depending on the process conditions - as ordinary or thermal-shrink film.

The purpose of blow film extrusion is to inject air, the pressure of which causes the plastic material to expand and giving it the right shape.

Extrusion process is carried out in the extrusion technological line. Construction and characteristics of the line depend on: the shape and dimensions of the product, material properties and desired quality and efficiency of extrusion. The film is obtained by extrusion with horizontal blowing (fig. 1), vertically up or vertically down. The resulting film is in the form of a thermoplastic sleeve.

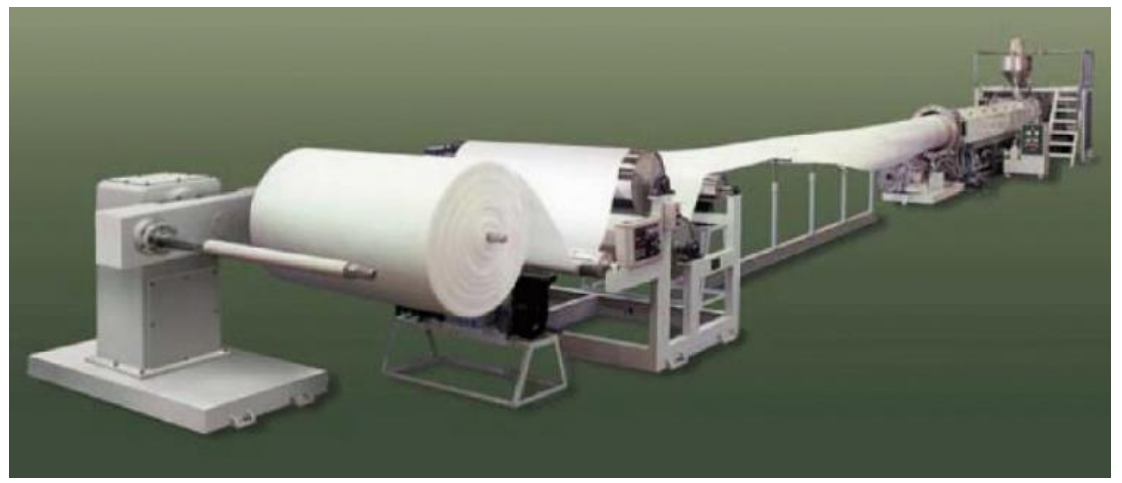

Fig. 1. IMG-Plastec porous film extrusion line - horizontal blow film extrusion [14] 
The blow film extrusion process produces packaging films that should be thin, strong and rigid. Good strength films are made of PE-HD polyethylene, which has high viscosity and is not very stretchy. Rigid films require high-density plastic, thin films (less than $30 \mu \mathrm{m}$ thick) are mainly made of low-viscosity PE-LD [6, 7].

Air is introduced into the film through the head, because the film sleeve is on one side limited by a flattening and collecting device. After the main cooling, the film is flattened by means of a flattening device. The receiving device consists of two rollers that pull the extruded film - the device passes through the flattened film sleeve, which should be free from wrinkles and folds. The cooled foil is wound on a roller of a winding device $[2,6,7]$.

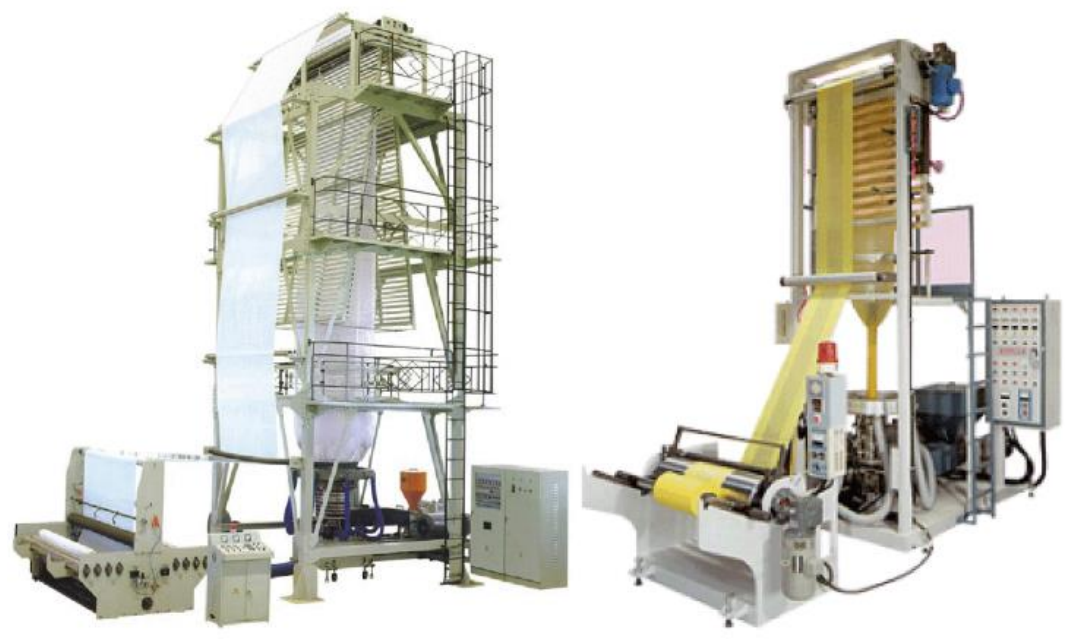

Fig. 2. Example of technological lines for the production of foil by vertically up blow film extrusion [18, 19]

The extrusion process with vertical blowing (fig. 2) is the most popular - it is used in the production of films of various sizes and with the use of any size device [9-11, 15]. Its advantage is that for large installations, no special working platforms are needed to position the extruder, head and drive. In the case of thick-walled plastic sleeves, the weight of the film, which still has to be shaped, is carried by the cooled material $[12,13,16,17]$.

\section{Research characteristics}

The purpose of the research was to determine the performance characteristics of the technological station for the production of blow film extrusion. Testing station for blow film extrusion includes: technological line for blow film extrusion W 25/M of the company "Metalchem" Torun and station for measuring the thickness of the film.

The blow film extrusion production line consists of:

- W-25 extruders,

- cross head,

- device that inflates the cooling air and blows it,

- flattening device,

- receiving device,

- winding device.

Basic technological data of the blow film extrusion line are as follows:

- capacity up to $8 \mathrm{~kg} / \mathrm{h}$,

- screw diameter $25 \mathrm{~mm}$,

- screw rotation $2.8 \mathrm{~s}^{-1}$,

- film thickness $30 \div 120 \mu \mathrm{m}$,

- film collection speed $0.046 \div 0.31 \mathrm{~m} / \mathrm{s}$.

The tool system of the blow film extrusion test stand is a cross (ring) extrusion head with a nozzle with a diameter of $d=90 \mathrm{~mm}$ and width of the annular gap of the outlet $g 0=0.8 \mathrm{~mm}$. The head has a system of three $600 \mathrm{~W}$ heaters, divided into two zones, with two temperature sensors built into the plasticizing system and a film cooling ring.

Cooling inflating device on the test bench consists of a $0.55 \mathrm{~kW} \mathrm{AC}$ motor, powered by $380 \mathrm{~V}$, connected to a fan, from which the air is pumped through a pipe and adjustable throttle to the expansion tank, from where it is then distributed through smaller diameter pipes to the cooling ring located in the extrusion head. 
Flattening device is made of flattening slats and a pair of flattening rollers mounted in the upper part of the extraction frame. The strips consist of two components: stationary and starting one. Flattening rollers are spring-pressed together.

Collecting device consists of two rollers made of metal covered with a layer of rubber on the cylindrical surface. One of the rollers is driven by an electric motor with a power of $0.25 \mathrm{~kW}$ and a speed of up to $46 \mathrm{~s}^{-1}$ via a chain reduction gear. As a result of the pressure of the rollers with the help of a spring, a friction force is created, necessary to set the second roller in motion and to move the flattened film between them.

Winding device consists of two rollers, one of which is driven directly by the motor of the collecting device the winding speed therefore depends on the stretching speed of the film. The maximum width of the wound foil is $400 \mathrm{~mm}$, while the inside diameter of the roll ranges from 74 to $84 \mathrm{~mm}$.

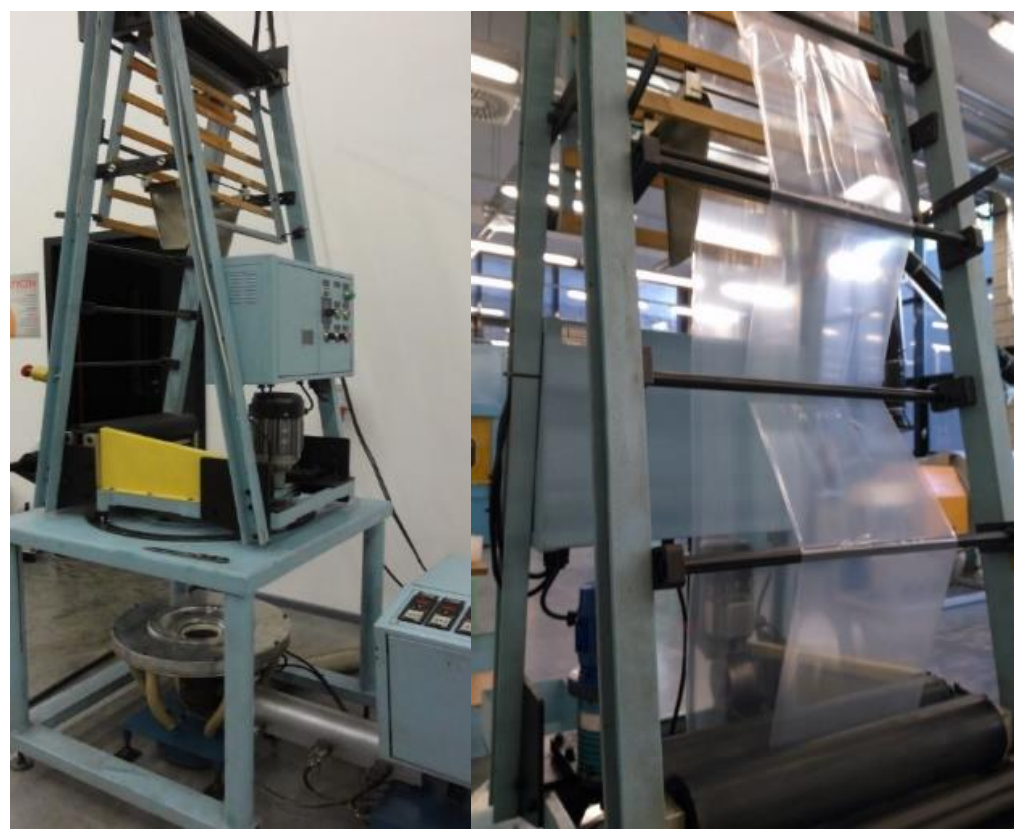

Fig. 3. Blow film extrusion technological station during the production of single-layer film

Malen-E FABS23D022 low density polyethylene was used in the research. This material contains antioxidants as well as anti-blocking and slip additives to prevent film from sticking. Its use in the production of thin films is possible due to favorable rheological characteristics. Temperature of the plasticizing system in individual zones for this material is: $150^{\circ} \mathrm{C}$ - in the feeding zone, $180^{\circ} \mathrm{C}$ - in the transformation zone, $190^{\circ} \mathrm{C}$ - in the dosing zone, $165^{\circ} \mathrm{C}$ - head temperature.

The blow film extrusion process is characterized by a degree of transverse stretching $R p$ equal to the degree of blowing, and a degree of longitudinal stretching $R w$ of the film.

Degree of transverse stretching $R p$ is defined as the ratio of the diameter $D$ of the tubular film to the diameter $d$ of the nozzle outlet opening (thickness of the film is omitted - due to its low value in relation to the listed values) in accordance with the relationship:

$$
R_{p}=\frac{D}{d}=\frac{2 B}{d \pi}
$$

where: $B$ - width of the flattened tubular film.

Degree of longitudinal stretching $R w$ of the film is defined as the ratio of the film removal speed to the speed, at which the extrusion leaves the nozzle head.

Using the relationship between process efficiency, extrusion speed and product thickness, a formula was obtained specifying the degree of stretching in the longitudinal direction:

$$
R_{\mathrm{w}}=\frac{g_{0} d}{g_{1} D}=\frac{g_{0}}{g_{1} R_{\mathrm{p}}}
$$


TABLE I. Results of measurement of roll speed, extrudate thickness (measured in four points and three planes) and average film thickness

\begin{tabular}{|c|c|c|c|c|c|c|c|}
\hline \multirow[b]{2}{*}{$\begin{array}{l}\text { Sample } \\
\text { number }\end{array}$} & \multirow{2}{*}{$\begin{array}{l}\text { Roller } \\
\text { rotational } \\
\text { speed } n \text {. } \\
\text { rev } / \mathrm{min}\end{array}$} & \multirow{2}{*}{$\begin{array}{l}\text { Measurement } \\
\text { plane }\end{array}$} & \multicolumn{4}{|c|}{ Film thickness, mm } & \multirow[b]{2}{*}{$\begin{array}{c}\text { Average film } \\
\text { thickness } g_{1} \\
\mathrm{~mm}\end{array}$} \\
\hline & & & $a$ & $b$ & $c$ & $d$ & \\
\hline \multirow{3}{*}{1} & \multirow{3}{*}{15} & $\mathrm{I}$ & 0.068 & 0.077 & 0.071 & 0.073 & \multirow{3}{*}{0.072} \\
\hline & & II & 0.078 & 0.073 & 0.073 & 0.075 & \\
\hline & & III & 0.071 & 0.069 & 0.072 & 0.068 & \\
\hline \multirow{3}{*}{2} & \multirow{3}{*}{30} & $\mathrm{I}$ & 0.040 & 0.039 & 0.042 & 0.040 & \multirow{3}{*}{0.040} \\
\hline & & II & 0.037 & 0.039 & 0.041 & 0.037 & \\
\hline & & III & 0.042 & 0.043 & 0.039 & 0.042 & \\
\hline \multirow{3}{*}{3} & \multirow{3}{*}{45} & $\mathrm{I}$ & 0.028 & 0.024 & 0.027 & 0.024 & \multirow{3}{*}{0.028} \\
\hline & & II & 0.030 & 0.029 & 0.029 & 0.029 & \\
\hline & & III & 0.024 & 0.027 & 0.029 & 0.030 & \\
\hline \multirow{3}{*}{4} & \multirow{3}{*}{60} & $\mathrm{I}$ & 0.022 & 0.017 & 0.021 & 0.022 & \multirow{3}{*}{0.020} \\
\hline & & II & 0.020 & 0.018 & 0.022 & 0.017 & \\
\hline & & III & 0.022 & 0.022 & 0.021 & 0.019 & \\
\hline \multirow{3}{*}{5} & \multirow{3}{*}{75} & I & 0.016 & 0.015 & 0.016 & 0.014 & \multirow{3}{*}{0.015} \\
\hline & & II & 0.014 & 0.016 & 0.017 & 0.015 & \\
\hline & & III & 0.015 & 0.015 & 0.015 & 0.017 & \\
\hline
\end{tabular}

TABLE II. Test results of the width and degree of transverse stretching of the film

\begin{tabular}{|c|c|c|c|c|c|}
\hline $\begin{array}{c}\text { Sample } \\
\text { number }\end{array}$ & $\begin{array}{c}\text { Roller rotational } \\
\text { speed } n . \text { rev/min }\end{array}$ & $\begin{array}{c}\text { Film sleeve width } \\
B, \mathrm{~mm}\end{array}$ & $\begin{array}{c}\text { Transverse stretch } \\
\text { degree } R_{\mathrm{p}}, \%\end{array}$ & $\begin{array}{c}\text { Film thickness } \\
g_{1}, \mathrm{~mm}\end{array}$ & $\begin{array}{c}\text { Longitudinal } \\
\text { stretching } \\
\text { degree } R_{\mathrm{w}} \%\end{array}$ \\
\hline 1 & 15 & 243 & 1.720 & 0.072 & 6.450 \\
\hline 2 & 30 & 238 & 1.684 & 0.040 & 11.876 \\
\hline 3 & 45 & 231 & 1.635 & 0.028 & 17.475 \\
\hline 4 & 60 & 223 & 1.579 & 0.020 & 25.332 \\
\hline 5 & 75 & 219 & 1.550 & 0.015 & 34.408 \\
\hline
\end{tabular}

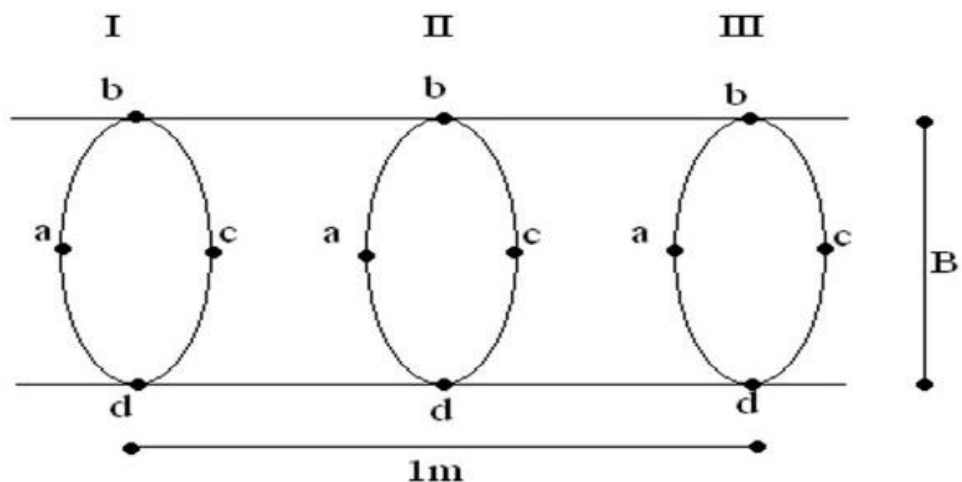

Fig. 4. Diagram of the foil sleeve: $a, b, c$ and $d$ - points where the thickness of the foil was measured; I, II and III - measurement planes

\section{Results}

Film thickness measurements were made at 12 points; four measurements at different lengths of film section in the form of a sleeve. The measurement scheme is presented in fig. 4. The same method of measurement was used for each of the five samples used for the tests.

The film thickness $g 1$ was determined using a Wilson Wolpert 200-01 DDL micrometer. It made it possible to measure in the range of $0 \div 25 \mathrm{~mm}$ with an accuracy of $0.001 \mathrm{~mm}$.

Width of the film was determined using a scale with an accuracy of $1 \mathrm{~mm}$.

Sample results of measurements and calculations are presented in tabs. I and II and in figs. 5 and 6. 


\section{Summary and final conclusions}

The blow film extrusion process is carried out correctly due to the appropriately selected extrusion parameters, i.e. rotational speed of the rollers, width of the annular gap of the outlet opening, temperature of the heating zones, inflation pressure and pressure of the blowing air.

Selection of appropriate materials for film production is also important. These, in turn, should be selected in terms of the use of the finished product. The wrong choice of material can lead to tearing of the film when blowing a hard plastic.

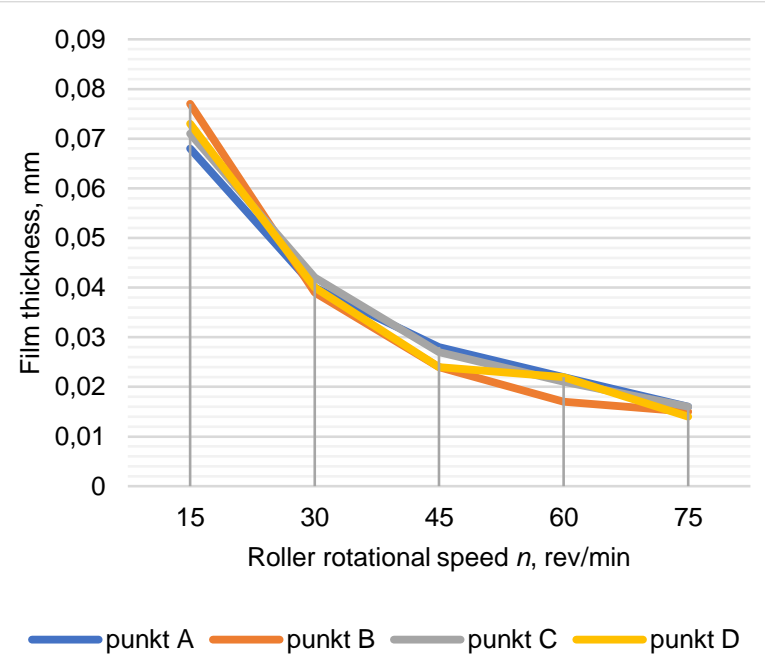

Fig. 5. Results of measurements of roll speed, extrudate thickness measured at four points for plane I

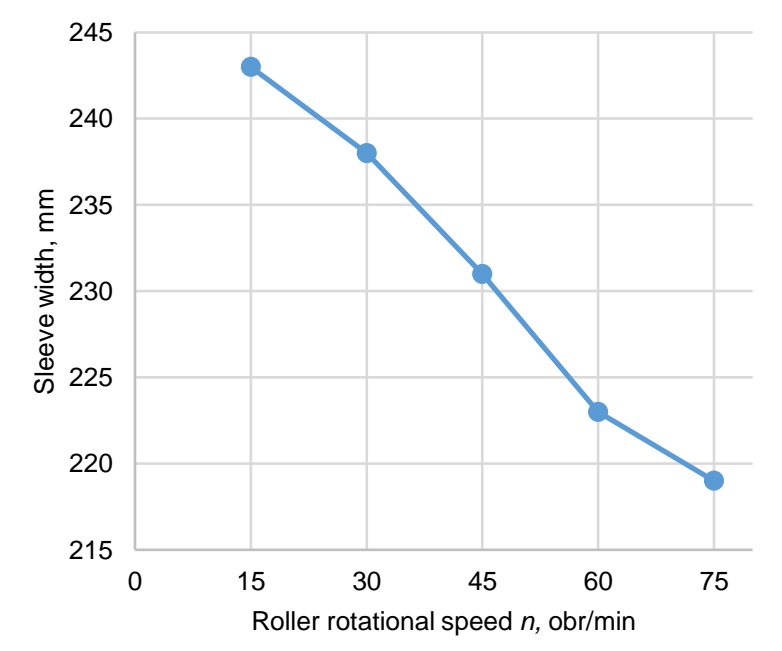

Fig. 6. Graph of the dependence of the film sleeve width on the speed of the receiving rollers

Tests and characteristics of the blow film extrusion process allow the following conclusions to be made.

Due to the use of Malen-E FABS 23D022 polyethylene for extrusion tests and correct selection of processing conditions (such as temperature in the extruder plasticizing system and temperature in the extrusion head), a sleeve film was obtained. The speeds, at which the rollers rotated, began at $15 \mathrm{rpm}$ and increased by $15 \mathrm{rpm}$ until they reached $75 \mathrm{rpm}$. A change in the rotational speed of the receiving rollers in the range from 15 to 75 rpm caused that the film thicknesses in each of the five samples are not uniform and range from 0.072 to 0.015 $\mathrm{mm}$. The film thickness decreases as the speed of the receiving rollers increases. Differences in film thickness within the same sample are mainly due to the mass flow rate of the material, diameter of the extruded tubular film, amount and pressure of blowing air, and speed of the film removal. Determined degree of film stretching $R w$ in the longitudinal direction depends on the conditions of technological process and in the event of changes in rotational speed, it increases with its increase from $6 \%$ at $15 \mathrm{rpm}$ to $34 \%$ at $75 \mathrm{rpm}$. Degree of film stretching $R p$ in the transverse direction is less dependent on the change in the speed of the rolls of the receiving device 
and at $15 \mathrm{rpm}$ is $1.72 \%$, and at $75 \mathrm{rpm}-1.55 \%$. When determining the extent of stretching in the transverse direction, there is a slight downward tendency when the revolutions of the rolls of the receiving device increase.

\section{REFERENCES}

[1] Grajewski F., Stieglitz H. „Extrudieren von weichen PVC-Folien”. Kunststoffe. 10 (2003): 169-172.

[2] Große M. „Wirtschaftlich und flexibel extrudieren”. Plastverarbeiter. 11 (2001): 52-53.

[3] Kaczmarek D., Wortberg J. „Holz aus dem Extruder”. Kunststoffe. 2 (2003): 18-23.

[4] Lutomirski S. „Metody stabilizacji grubości folii w procesie jej wytwarzania metodą wytłaczania ze swobodnym rozdmuchiwaniem". Przetwórstwo Tworzyw. 2 (2005): 50-52.

[5] Łączyński B. „Metody przetwórstwa tworzyw sztucznych”. Warszawa: WNT, 1985, 307-313.

[6] Mascia L., Zhao J. "Extrusion of polymers in the plastic". Advances in Polymer Technology". 5 (1990): 87-99.

[7] Michaeli W., Schmitz T. „Folienextrusion: PET-Extrusion ohne Vortrocknung?”. Kunststoffe. 8 (2004): 114119.

[8] Sikora R., Garbacz T. „Ocena jakości wytworów otrzymywanych metodą wytłaczania z rozdmuchiwaniem". Polimery. 6 (2000): 540-545.

[9] Sikora R., Jachowicz T. „Wpływ czasu ochładzania na skurcz przetwórczy wytworów otrzymywanych metodą wytłaczania z rozdmuchiwaniem". Polimery. 11 (2000): 713-716.

[10] Stasiek J. „Kierunek rozwoju linii do wytłaczania z rozdmuchiwaniem folii, w tym z rozdmuchiwaniem dwustopniowym”. Przetwórstwo Tworzyw. 4 (2005): 15-17.

[11] Stasiek J. „Współczesne technologie i urządzenia do wytłaczania folii metodą wytłaczania z rozdmuchiwaniem". Polimery. 3 (2005): 170-175.

[12] Wilczyński K., Nastaj A., Krutysz P. „Optymalizacja procesu wytłaczania jednoślimakowego tworzyw sztucznych". Mechanik. 10 (2003): 83-86.

[13] Zawistowski H. „Zasady wytłaczania folii rozdmuchiwanych”. Warszawa: Plastech Wydawnictwo Poradników i Książek Technicznych, 1999, 131-151.

[14] www.imgplastec.com (dostęp: 04.02.2019).

[15] www.bbmachinery.com (dostęp: 04.02.2019).

[16] www.chinfach.com.tw (dostęp: 04.02.2019).

[17] www.rommel.de (dostęp: 04.02.2019).

[18] www.chinajinda.en (dostęp: 04.02.2019).

[19] www.cacoplastics.com (dostęp: 04.02.2019). 